\title{
A poorly diversified trilobite association from the lower Emsian (Lower Devonian) in the Sankt Vith area (East Belgium)
}

\author{
Allart P. VAN VIERSEN ${ }^{1 *} \&$ Peter TAGHON ${ }^{2}$
}

\author{
${ }^{1}$ Natuurhistorisch Museum Maastricht, De Bosquetplein 6-7, 6211 KJ Maastricht, The Netherlands; apvanviersen@gmail.com. \\ ${ }^{2}$ Deinse Horsweg 12, 9031 Gent, Belgium; peter.taghon@telenet.be. \\ * corresponding author.
}

\begin{abstract}
A poorly diversified trilobite association is recorded from an outcrop near the village of Breitfeld, Sankt Vith area, East Belgium. The co-occurrence of Arduennella maillieuxi (Asselberghs, 1923) and Burmeisterella quadrispinosa Wenndorf, 1990 in the Breitfeld locality is suggestive of an early lower Emsian age. The outcropping rocks are provisionally attributed to the lower part of the Our Formation (lower Emsian) as opposed to previous assignment to the "Quartzophyllades de Saint Vith" or Sankt Vith Formation (Pragian). Some nomenclatoral notes are provided on the types of A. maillieuxi as the lectotype could not be traced; a cast of the lectotype as well as several paralectotypes of this species are illustrated. Our material of B. quadrispinosa includes cephalic remains that bring new insights into the morphology of this species. A third species, Treveropyge hellemondi sp. nov., is furthermore described. Palaeobiogeographic affiliations of the trilobite association are discussed. A tentative first step is proposed towards trilobite-based correlations of Emsian strata in the Ardenno-Rhenish Mountains.
\end{abstract}

KEYWORDS: Trilobites, systematic palaeontology, biostratigraphy, palaeobiogeography.

\section{Introduction}

Contrary to the situation in South Belgium where Devonian trilobites have been the focus of numerous contemporary studies, only few papers have dealt with taxa from East Belgium (Franke, 2006; Hellemond et al., 2019; van Viersen, 2013; van Viersen \& Prescher, 2009). Nearly a century ago Asselberghs (1923) reported a poorly diversified, Early Devonian trilobite association from an outcrop near Breitfeld (Sankt Vith (Saint Vith in French) area, East Belgium). Although Asselberghs described and illustrated only one trilobite species, Homalonotus maillieuxi Asselberghs, 1923, he mentioned the occurrences of several others. The present paper aims to document the Breitfeld trilobite association fully, and to discuss its potential for biostratigraphic correlations of Emsian trilobites in the Ardenno-Rhenish Mountains as well as its palaeobiogeographic affinities.

\section{Geological context}

Locality B-117 ("P1. Saint-Vith 1" on the field maps of Maillieux that are kept by the Institut royal des Sciences naturelles de Belgique in Brussels (IRSNB)), southwest of the village centre of Breitfeld, East Belgium (Figs 1, 2); probably lower part of the Our Formation (lower Emsian).

This outcrop, which is no longer accessible at present, was located along the former Sankt Vith-Burg Reuland railway tracks. These tracks were part of the dismantled Vennbahn railway line that ran across the Hohes Venn from Troisvierges (Luxemburg) to Aachen (Germany). Asselberghs $(1921,1923)$ reported what he termed a brachiopod-dominated macrofauna from the "phyllades et schistes phylladeux du Hunsruckien supérieur", while noting lithological similarities to the upper part of the Hunsrückschiefer

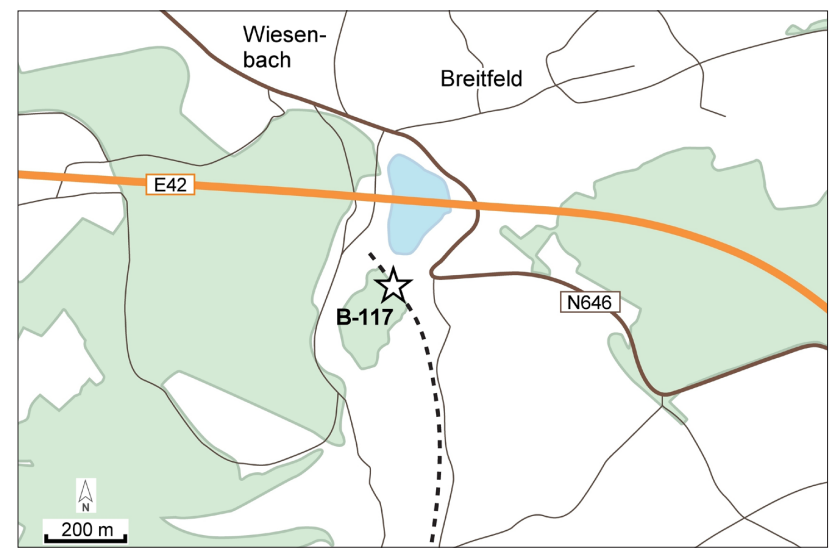

Figure 1. Geographic map of the studied area with the Breitfeld locality (B-117) indicated. The black dotted line indicates part of the former Vennbahn railway line. in the Rhenish Mountains. Later, Asselberghs (1927) introduced the term "Quartzophyllades de Saint Vith" for the increasingly neritic, northern to northeastern facies of the "Hunsruckien supérieur". In his classic work on the Lower Devonian of the Ardennes Asselberghs (1946) provided a more detailed definition of the Sankt Vith facies. He also showed its geographic extent on a map as being widely distributed in East Belgium and inclusive of the area of Sankt Vith and Breitfeld (Fig. 2B). Vandenven (1990) recognised the Sankt Vith facies as a distinct stratigraphic unit in referring to it as the Sankt Vith Formation (Pragian). Contrary to Asselberghs (1946), the geological map of Vandenven (1990) attributed a restricted geographic extent to the Sankt Vith Formation. More specifically, Vandenven (1990) did not place the Breitfeld locality in this formation, but in the early Emsian Breitfeld-Steinbrück Formation that was proposed by him (Fig. 2B). Dejonghe et al. (2017) noticed that the outcrops used by Vandenven (1990) to establish the Breitfeld-Steinbrück Formation had disappeared or become inaccessible and so they proposed the Our Formation instead. Dejonghe $(2013,2019)$ and Dejonghe et al. (2017) furthermore showed the Sankt Vith Formation to be a lateral facies within the lower part of the Pragian La Roche Formation. According to L. Dejonghe (pers. comm. with AVV in July 2019) there is currently no justification for the recognition of the Sankt Vith facies as a distinct formation.

The assignment of the Breitfeld outcrop to the lower part of the Our Formation is not entirely unequivocal. According to Dejonghe et al. (2017) a lower boundary of this formation cannot be precisely established due to its progressive variations in lithology. Furthermore, the possibility cannot be excluded that the contact between the Sankt Vith facies and the Our Formation in the area of study is tectonic. Vandenven (1990, p. 104) indicated the Troisvierges-Malsbenden Fault on his map just south of Sankt Vith ('3VM' in our Fig. 2B). Although Vandenven did not directly observe this feature, he considered it to be responsible for the absence of the summit and probably also the middle part of the Sankt Vith Formation there (for discussion on the TroisviergesMalsbenden Fault see Cambier \& Dejonghe, 2010 and Dejonghe, 2019). We were unable to access the Breitfeld outcrop and we have been equally unsuccessful at finding a section in the area to yield a similar trilobite association for comparison. Consequently, it is not possible to position the B-117 locality in the lower part of the Our Formation other than based on the circumstantial evidence of its position on the geological map of Vandenven (1990), the putative (chiefly) early Emsian age of the Our Formation and the biostratigraphic data presented herein.

Besides Homalonotus maillieuxi (the type species of Arduennella Wenndorf, 1990), trilobites reported by Asselberghs (1923) were Cryphaeus drevermanni (the type species of Dunopyge Struve in Becker \& Jansen, 1998), Homalonotus aculeatus and Homalonotus champernownei? (both species of Burmeisterella Reed, 1918) and Homalonotus planus (a species

https://doi.org/10.20341/gb.2019.011 


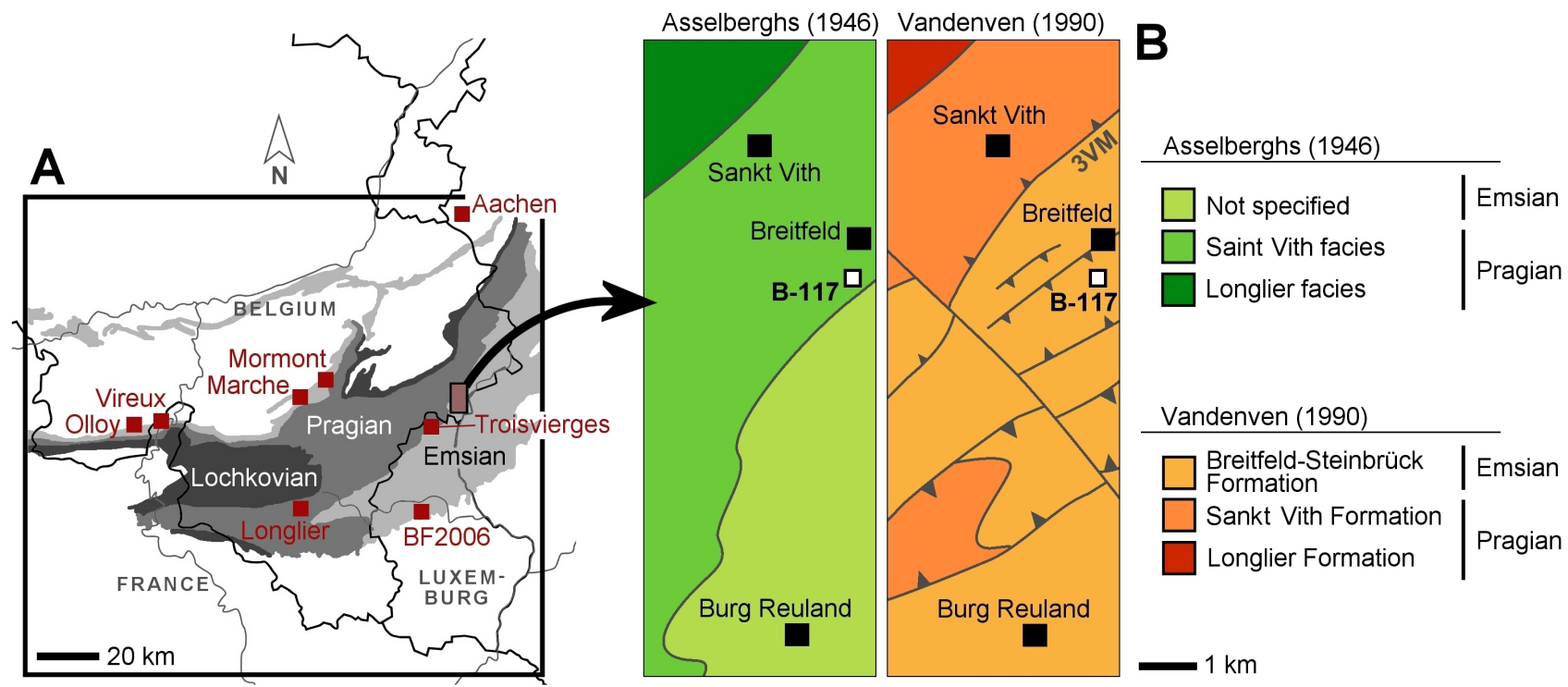

Figure 2. A. Overview geological map of southeast Belgium, northern France, Luxemburg and western Germany with key localities and Lochkovian, Pragian and Emsian strata indicated. 'BF2006' stands for the Reideschbaach locality of Basse \& Franke (2006). B. Geological maps of the studied area after Asselberghs (1946) and Vandenven (1990) with the Breitfeld locality (B-117) indicated. '3VM' stands for the Troisvierges-Malsbenden Fault (tentative, after Vandenven, 1990).

of Wenndorfia Sandford, 2005). According to Asselberghs (1921, 1923 ) the trilobites from the Breitfeld locality were collected by E. Maillieux and deposited in the IRSNB. Maillieux's material was examined by us and is assigned here to Arduennella maillieuxi (Asselberghs, 1923), Burmeisterella quadrispinosa Wenndorf, 1990, Wenndorfia sp., Treveropyge hellemondi sp. nov. and Asteropyginae gen. \& sp. indet. Specimens of $A$. maillieuxi and B. quadrispinosa are sometimes contained within the same rock slab, demonstrating their co-occurrence in the Breitfeld locality.

\section{Systematic palaeontology}

Material and methods. All specimens were whitened with ammonium chloride prior to photography. The material is housed by the IRSNB. Morphologic terminology follows that of the Revised Trilobite Treatise (Whittington \& Kelly, 1997).

Family Homalonotidae Chapman, 1890

Subfamily Homalonotinae Chapman, 1890

\section{Genus Arduennella Wenndorf, 1990}

Type species. Homalonotus maillieuxi Asselberghs, 1923 from the Emsian of Belgium.

\section{Arduennella maillieuxi (Asselberghs, 1923)}

(Figs 3A-H, 4)

v 1921 H. nov. sp. ab. (sic); Asselberghs, p. 142 [as a species of Homalonotus].

v * 1923 Homalonotus Maillieuxi (sic) Asselberghs, pp. 3032, pl. 1, figs 1-9.

v 1927 Homalonotus Maillieuxi (sic); Asselberghs, p. 209.

v 1933 Homalonotus (Burmeisteria) Maillieuxi (sic); Maillieux, p. 54.

v 1940 Homalonotus (Burmeisteria) Maillieuxi (sic); Maillieux, p. 23.

v 1946 Homalonotus (Burmeisteria) maillieuxi; Asselberghs, p. 337.

1975 D.? maillieuxi; Tomczykowa, tabs II, III [as a questionable species of Digonus].

1990 Arduennella maillieuxi; Wenndorf, pp. 140-143, pl. 4, figs 5-10.

non 1994 Arduenella maillieuxi (sic); Kennedy, 24, 25, pl. 5, figs 5, 7, 16 [=? Digonus sp.].

1997 Arduennella maillieuxi; Müller, pp. 8, 16.

1997 Arduenella maillieuxi; Müller, p. 8, unnumb. figs [lapsus calami].
1998 Arduennella maillieuxi; Schraut, pp. 64, 65, tab. 2, pl. 1, figs 7,8 .

2000 Arduennella maillieuxi; Schraut, pp. 381, 382, pl. 7, figs 1-6.

2004 Arduennella maillieuxi; Basse \& Weddige, p. 149.

2004 Arduennella maillieuxi; Jansen et al., p. 64, pl. 1, fig. 9.

2004 Arduenella maillieuxi; Jansen et al., p. 65 [lapsus calami].

2004 Arduennella maillieuxi; Müller in Basse \& Müller, pp. 89, 90, pl. 33, 426-432, pl. 34, figs 433-443.

2005 A. maillieuxi; Sandford, tab. 1 [non UK occurrence].

2006 Arduennella maillieuxi; Basse \& Franke, p. 13.

2008 Arduennella maillieuxi; Alberti, pp. 39, 40, figs 2, 3.

v 2009 Arduennella maillieuxi; van Viersen \& Prescher, p. 8. 2011 Arduenella maillieuxi (sic); Müller, fig. 12.

Material. IRSNB a13441, plaster cast of paralectotype cranidium (Fig. 3A), IRSNB a13444, plaster cast of the lectotype pygidium (Fig. 3D), IRSNB a13445, a13447, two external moulds of paralectotype pygidia (Fig. 3E, G), IRSNB a13442, a13446, two internal moulds of partial paralectotype cephala (Fig. 3B, F), IRSNB a13443, a13448, two internal moulds of paralectotype pygidia (Fig. 3C, H). All from the lower part of the Our Formation of B-117, Breitfeld (= type locality and horizon).

Discussion. Asselberghs (1923, pl. 1, figs 1-9) illustrated several cephalic and pygidial remains of this species but he did not designate a holotype. Wenndorf (1990) selected the pygidium figured by Asselberghs (1923, pl. 1, fig. 9a, b) as the lectotype while referring to its whereabouts as the Asselberghs collection of the IRSNB. At the time of writing of the present note, none of the original specimens figured by Asselberghs (1923) could be traced in the IRSNB. However, we identified two plaster casts in the Maillieux collection of the IRSNB along with a hand-written label by E. Maillieux from 1930. One of these casts (Fig. 3D) belongs to the lectotype pygidium, and the other (Fig. 3A) to the paralectotype cranidium that was figured by Asselberghs (1923, pl. 1, fig. 2). The cast of the lectotype (but also that of the paralectotype cranidium) was made of the external mould; it is of satisfactory quality and shows characteristic features of this species. Thus, the designation of a neotype is not necessary. Other specimens of $A$. maillieuxi from the type locality were furthermore identified by us in the Maillieux collection of the IRSNB. Although none of these were figured or individually referred to by Asselberghs (1923) he did mention that the description of his species was based on "a dozen cephalic remains" (ibid., p. 30) and "nine pygidia ... and three others" (ibid., p. 31). The specimens in the Maillieux collection are labelled as having been examined 
by E. Asselberghs in 1921. They should, thus, be considered part of the type series that collectively constituted the namebearing type. These specimens were syntypes until Wenndorf (1990) selected the lectotype; as a consequence of that act they all became paralectotypes. Several specimens are illustrated in the present note.
Casts of the types figured by Asselberghs (1923) along with hand-written labels by K.-W. Wenndorf are kept by the Senckenberg Institute (AVV, pers. comm. with M. Basse in September 2019); one of these, a cast of the internal mould of the lectotype, was figured by Müller (in Basse \& Müller, 2004, pl. 33, fig. 426). Searches by the authors of the present note in the
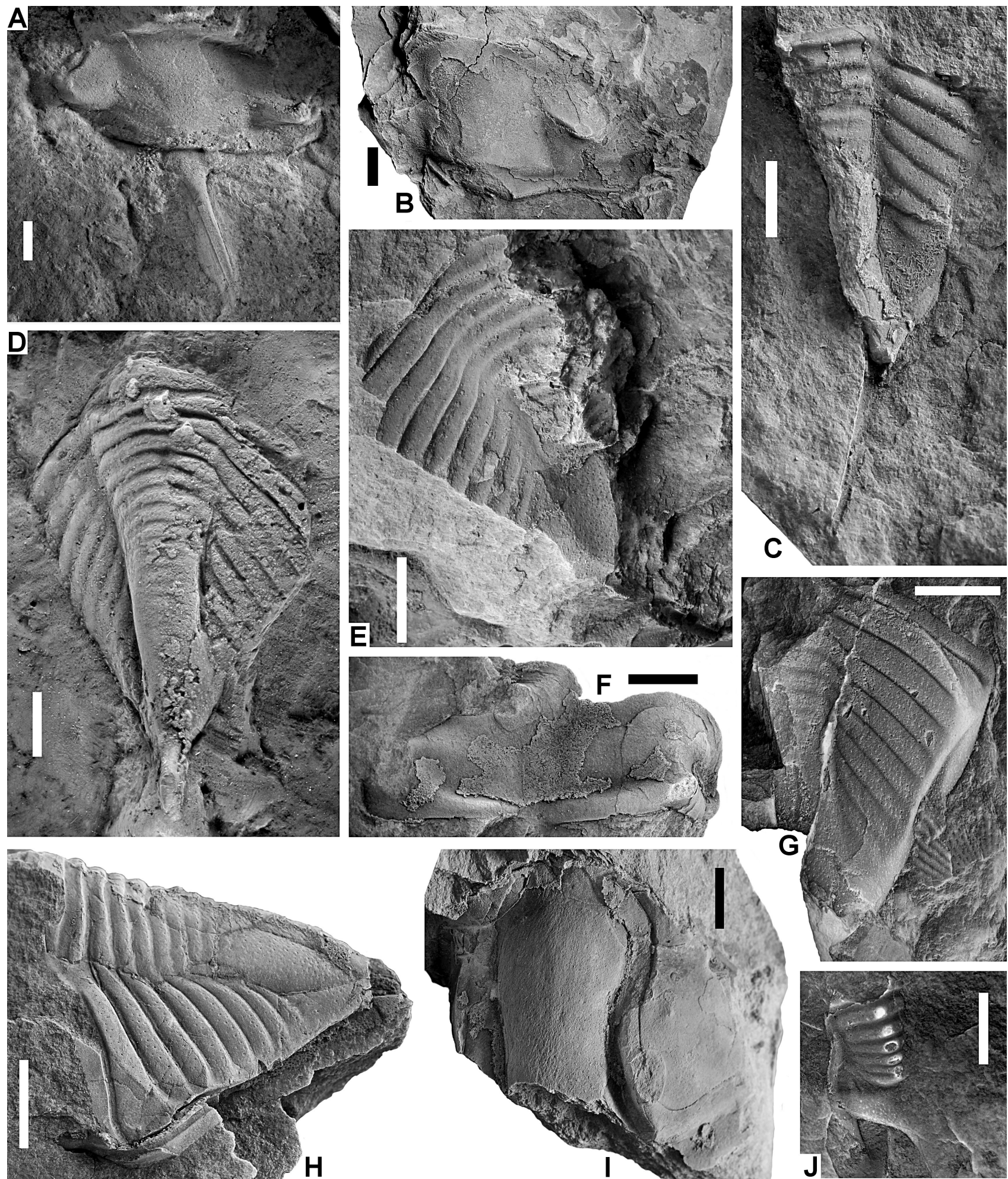

Figure 3. Trilobites from the lower part of the Our Formation at B-117, Breitfeld.

A-H. Arduennella maillieuxi (Asselberghs, 1923). A. Plaster cast of paralectotype cranidium, IRSNB a13441, in dorsal view. B. Paralectotype internal mould of a cephalon, IRSNB a13442, in dorsal view. C. Paralectotype internal mould of a pygidium, IRSNB a13443, in dorsolateral view. D. Plaster cast of lectotype pygidium, IRSNB a13444, in dorsal view. E. Paralectotype external mould of a pygidium, IRSNB a13445, in dorsal view. F. Paralectotype internal mould of a fragmentary cephalon, IRSNB a13446, in dorsal view. G. Paralectotype external mould of a pygidium, IRSNB a13447, in dorsolateral view. H. Paralectotype internal mould of a pygidium, IRSNB a13448, in lateral view.

I. Wenndorfia sp. Internal mould of an incomplete cephalon, IRSNB a13449, in dorsal view.

J. Asteropyginae gen. \& sp. indet. External mould of a fragmentary pygidium (digitally inverted), IRSNB a13450, in dorsal view.

All scale bars represent $5 \mathrm{~mm}$. 
Asselberghs collection of the Katholieke Universiteit Leuven in 2019 did not yield any material of this species.

The morphology of Arduennella maillieuxi was documented by Wenndorf(1990), Müller (in Basse \& Müller, 2004) and Alberti (2008) mostly based on material from Germany. In our opinion, the conspecific relationship of the specimens from the Belgian and various German localities is not certain. A revision of $A$. maillieuxi would be timely but is beyond the scope of the present note (AVV, in preparation). In addition to previously published descriptions, the presence of numerous small pits on the internal moulds of pygidia (e.g. Fig. 3H) is mentioned by us. The external moulds (e.g. Fig. 3E, G) show the impressions of similarly distributed pits, dorsally on pygidia and cephala which suggests that the two are associated. From this we deduce that $A$. maillieuxi may have had pit-tubercles with pore canals (cf. Størmer, 1980, p. 243, fig. 1d). The apparent absence of these pits in the German material may be due to unfavourable taphonomic conditions. Alberti (2008, p. 39, fig. 2) illustrated a cranidium from the Rhenish Mountains (Taunus) that shows distinct lateral glabellar lobation. This feature is weakly developed in the specimens from the Rhenish Mountains (Westerwald) figured by Müller (in Basse \& Müller, 2004, pl. 34, figs 433, 435-437, 440, 443); it is absent in the specimens from Breitfeld. The reconstructions of Wenndorf (1990, p. 141, fig. 56) and Müller (in Basse \& Müller, 2004, p. 89, fig. 7) show a narrow glabella anterior to S0; this feature is widened (tr.) in the reconstruction by Alberti (2008, p. 40, fig. $3)$. The slender base of the pygidial terminal spine in Alberti's reconstruction is probably more similar to the Belgian material than is the broad spine in Wenndorf's and Müller's drawings. Our line drawing (Fig. 4) was based on the reconstruction by Alberti (2008) and subsequently modified to emphasise the broad glabella, the long occipital spine, and the elongated subtriangular pygidium with posteriorly tapered and cylindrically vaulted (tr.) axis, in order to characterise the topotypical material from Belgium.

Basse \& Müller (2016) pointed out that Kennedy's (1994) pygidia of $A$. maillieuxi from England are possibly deformed Digonus specimens. Kennedy (1994) commented on the incompleteness of his specimens but argued that they show trademarks of this species nonetheless. The only feature mentioned by him to potentially support that assignment is the acuminate terminal piece of one pygidium (Kennedy, 1994, pl. 5,

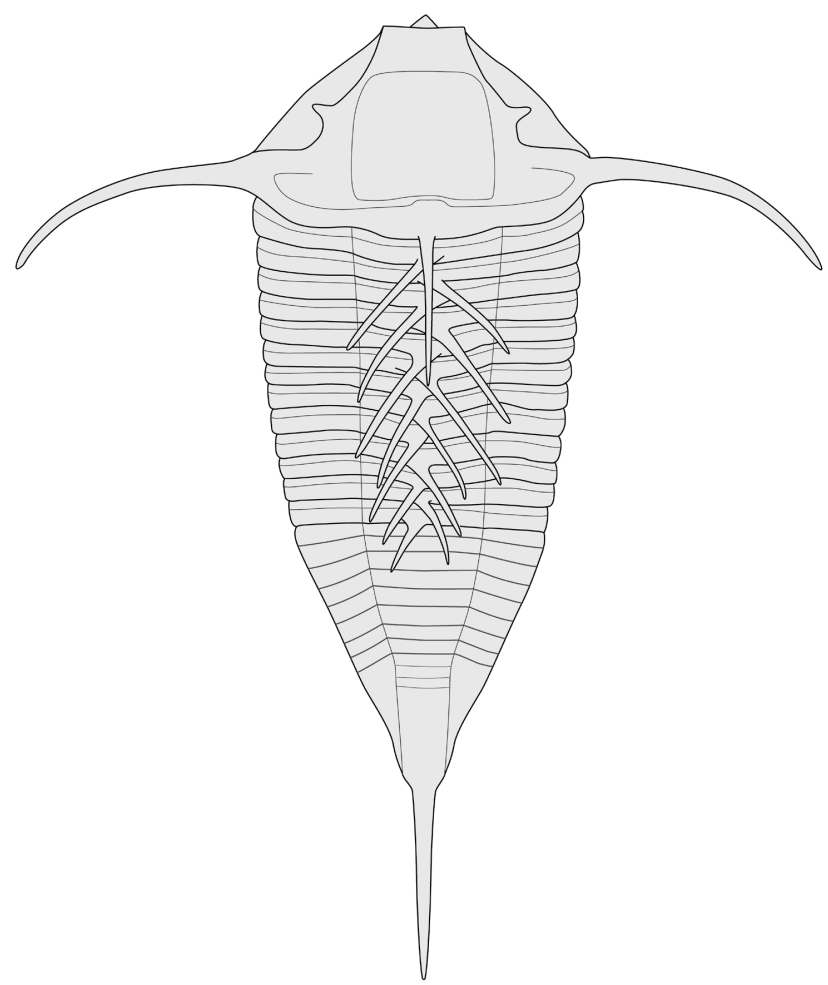

Figure 4. Reconstruction of topotypical Arduennella maillieuxi (Asselberghs, 1923). Adopted from Alberti (2008) and modified. Thorax after specimens from the Rhenish Mountains. figs 7, 16). However, that specimen has the elongated triangular terminus of a Digonus pygidium with a short, sharply pointed, upward curved tip; it does not resemble pygidia of Arduennella from the Ardenno-Rhenish Mountains. The previous standpoint of Basse \& Müller (2016) is therefore supported by us. Thus, the occurrence of Arduennella in England, despite the presence of strata to potentially bear its members in terms of age and lithology, is at least doubtful.

Basse \& Müller (2016) suggested that Schraut's (1998, 2000) pygidia of A. maillieuxi from the Pragian in Morocco could be representatives of the "Digonus ornatus ornatus group". The distinctly vaulted (tr.) axis in the figures of Schraut (2000, pl. 7 , figs $1 b, 2 b$ ), especially posterior to the last pleurae where it rises high above the pleural lobe, is typical of Arduennella and not known to us from any Digonus. Schraut's specimens are here regarded as a potentially new species of Arduennella.

\section{Genus Wenndorfia Sandford, 2005}

Type species. Homalonotus mutabilis Koch, 1880 from the Emsian of Germany.

\section{Wenndorfia sp.}

(Fig. 3I)

v 1921 H. planus; Asselberghs, p. 142 [as a species of Homalonotus].

v 1923 Homalonotus planus; Asselberghs, p. 29.

v 1927 H. planus; Asselberghs, p. 209.

Material. IRSNB a13449, internal mould of a partial cephalon, from the lower part of the Our Formation of B-117, Breitfeld.

Discussion. Wenndorfia appears to be a rare trilobite in the Breitfeld locality with but a single cephalon available for study. Based on its age and general morphology this specimen might be assigned to Wenndorfia plana (Koch, 1883) from coeval strata in the Rhenish Mountains but its poor preservation precludes a definite assignment. Of note are the fine pits on the glabella of our cephalon.

\section{Genus Burmeisterella Reed, 1918}

Type species. Homalonotus (Burmeisteria) elongatus Salter, 1865 (a primary homonym replaced with Burmeisterella neoelongata by Basse, 2007) from the Emsian of England.

Discussion. Burmeisterella is widely distributed in Pragian to Emsian strata in the Ardenno-Rhenish Mountains. A single species, B. aculeata (Koch, 1883), is known from the Pragian which has comparatively small spines. It was followed up by several species in the early Emsian, appearing successively in the fossil record but with overlapping stratigraphic ranges (Fig. 8). This diversification is accompanied by an increase of spine sizes and numbers in some species, perhaps in response to durophagous predation pressure from cephalopods or gnathostomes.

Besides these general trends, members of Burmeisterella show moderate variations of the dorsal spine patterns that sometimes overlap between species, making the current classification far from satisfactory. Müller (in Basse \& Müller, 2004) commented that the identifications of isolated sclerites are not rarely equivocal. Indeed, single cranidia or pygidia can be assigned to $B$. armata, B. aculeata or $B$. vixarmata Wenndorf, 1990, depending on their spine patterns. Nonetheless, Müller (in Basse \& Müller, 2004) considered spine pairs on the pygidial axis to be characteristic of B. aculeata and two pairs of spines on the pygidial pleurae (one on the first, and another on the third, fourth or fifth pleurae) to be characteristic of $B$. armata. A disarticulated complete specimen (exuvia) of B. armata from the lower Emsian (presumably Our Formation) of Consthum, Luxemburg, figured by van Viersen \& Prescher (2009, pl. 5, fig. 4), however, combines spines on the first and fifth pairs of pygidial pleurae as well as spine pairs on the pygidial axis. Such seemingly random (at least until more data become available) disparities lead us to hypothesise that in some 
species of Burmeisterella gene expression of dorsal spines may not have been strictly regulated. The inclusion of spine patterns in species diagnoses is a potential source of confusion and probably best avoided for taxa involved.

Burmeisteria (Digonus?) delattrei Pillet \& Waterlot, 1983 from the upper part of the Vireux Formation (late lower Emsian) in Vireux-Molhain, northern France, was recognised as a member of Burmeisterella by Sandford (2005). The specimens figured by Pillet \& Waterlot (1983, pl. 4, figs 1-16) have shallow lateral glabellar furrows and show only single spines on the L1 lateral glabellar lobes and on the first pair of pygidial pleurae. These same features were considered by Wenndorf (1990) and Müller \& Alberti (2010) to be diagnostic of Burmeisterella vixarmata from the Klerf Formation (late lower Emsian) in Luxemburg and the Eifel. This leads us to regard B. vixarmata as a junior subjective synonym of $B$. delattrei.

\section{Burmeisterella quadrispinosa Wenndorf, 1990}

(Figs 5, 6)

1921 Homalonotus aculeatus; Asselberghs, p. 142.

1921 H. Champernownei? (sic); Asselberghs, p. 142 [as a species of Homalonotus].

1923 H. aculeatus; Asselberghs, p. 29.

1923 H. Champernownei? (sic); Asselberghs, p. 29.

1927 Homalonotus aculeatus; Asselberghs, p. 209.

v 2009 Burmeisterella quadrispinosa; van Viersen \& Prescher, p. 8, pl. 5, fig. 5.

Material. IRSNB a13451, internal mould of a cranidium (Fig. 5A), IRSNB a13452, internal mould of a thoracopygidium (Fig. 5B), IRSNB a13453a+b, external and internal moulds of
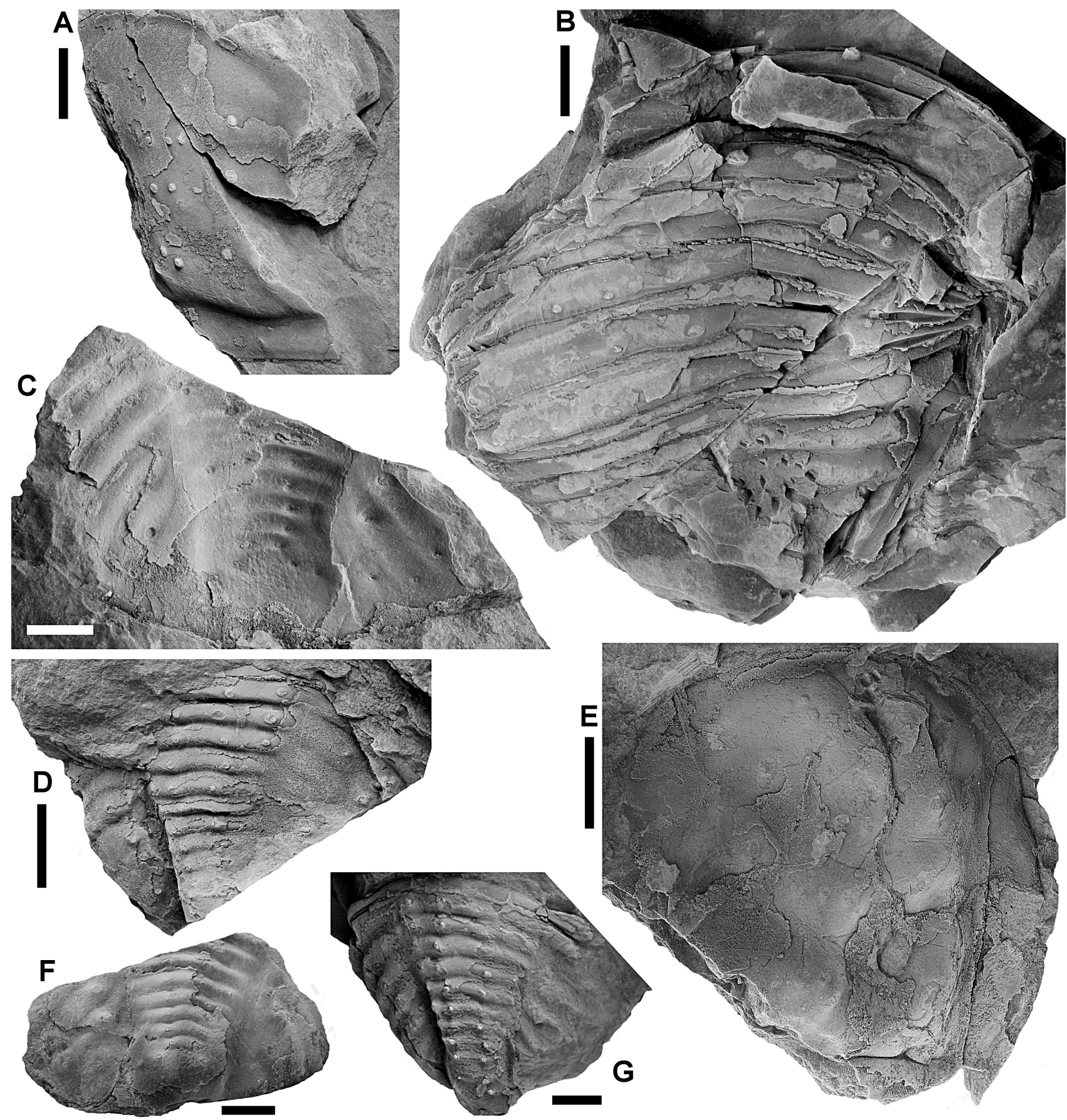

Figure 5. Burmeisterella quadrispinosa Wenndorf, 1990 from the lower part of the Our Formation at B-117, Breitfeld.

A. Internal mould of a cranidium, IRSNB a13451, in dorsal view. B. Internal mould of a thoracopygidium, IRSNB a13452, in dorsal view of thorax. C. External mould of a pygidium, IRSNB a13453a, in dorsal view. D. Internal mould of a pygidium, IRSNB a13453c (on same rock slab as IRSNB a13453a), in dorsal view. E. Internal mould of a cephalon, IRSNB a13454, in dorsal view. F. Internal mould of a pygidium, IRSNB a13453b (counterpart of IRSNB a13453a), in dorsal view. G. Internal mould of a pygidium, IRSNB a12691, in dorsal view. 


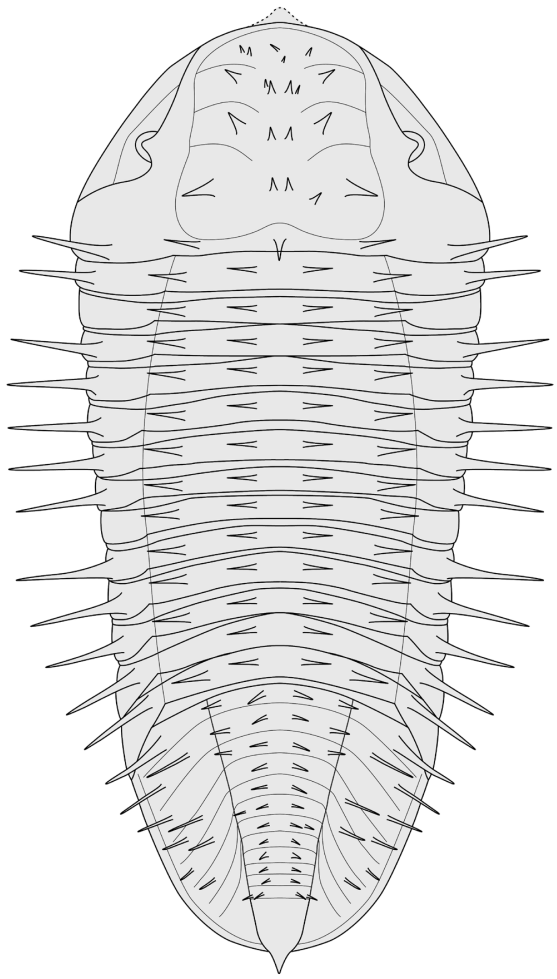

Figure 6. Reconstruction of Burmeisterella quadrispinosa Wenndorf, 1990. Adopted from Wenndorf (1990) and modified. Rostral plate is not known.

a pygidium (Fig. 5C, F), IRSNB a13453c, internal mould of a pygidium (Fig. 5D) (on the same rock slab as IRSNB a13453a), IRSNB a13454, internal mould of a cephalon (Fig. 5E), IRSNB a12691, internal mould of a pygidium (Fig. 5G). All from the lower part of the Our Formation of B-117, Breitfeld.

Discussion. This species was documented by Wenndorf (1990) and Müller (in Basse \& Müller, 2004) but the cephalic morphology was only known from very fragmentary material. We record a partial cranidium and a cephalon that show distinct lateral glabellar lobation (at least on the internal moulds) and the bases of a single thick spine on L1 and slightly smaller ones on L2 and L3. The bases of three spine pairs are present centrally between lateral glabellar pairs L1, L2 and L3. Several seemingly randomly positioned bases of smaller spines are discernible adjacent to the central spine pairs as well as in the area between the anteriormost spine pair and the anterior border furrow. Large spines principally come in axial-symmetric pairs on the entire dorsal exoskeleton but this rule is not inviolable as the Belgian material also shows. Wenndorf (1990) typified the spine patterns on the pygidial pleural fields of $B$. quadrispinosa as highly variable. The pygidia from Breitfeld appear to be more spiny than Wenndorf's material, often with two spines on a single pleural band instead of one. In order to complement the photos of the cephalic remains and to demonstrate the particular spine distribution, we provide a reconstruction of B. quadrispinosa (Fig. 6) largely created after the drawings by Wenndorf (1990) (thorax, pygidium and partial cephalon) and B. armata (cephalon), incorporating modifications of cephalic and pygidial proportions and spine patterns after the Belgian material.

Family Acastidae Delo, 1935

Subfamily Asteropyginae Delo, 1935

\section{Genus Treveropyge Struve, 1958}

Type species. Asteropyge (Asteropyge) prorotundifrons Richter \& Richter, 1943 from the Emsian of Germany.

\section{Treveropyge hellemondi sp. nov.}

(Fig. 7)

v 1921 Cryphaeus Drevermanni ab. (sic); Asselberghs, p. 142 .

v 1923 Cryphaeus Drevermanni (sic); Asselberghs, p. 29.

v 1927 Asteropyge Drevermanni (sic); Asselberghs, p. 209.

cf. e.p. 2006 Pilletina luxemburgensis Basse, Müller \& Franke, pp. 248-250, pl. 1, figs 6, 7 [only SMF 58703b].

Etymology. Named after Anthonie Hellemond, in recognition of his contribution to Belgian palaeontology.

Holotype. IRSNB a13457a+b, external mould of a pygidium plus plaster cast (Fig. 7D-F).

Paratypes. IRSNB a13455a+b+c, internal and external moulds of a cephalon plus plaster cast (Fig. 7A, B), IRSNB $\mathrm{a} 13456 \mathrm{a}+\mathrm{b}$, internal and external moulds of a cephalon (Fig. 7C) and IRSNB a13458, external mould of a pygidium (Fig. 7G). All from type locality and horizon.

Type locality and horizon. B-117, Breitfeld; lower part of the Our Formation, lower Emsian.

Diagnosis. S2 well-developed, even abaxially. Entire glabella covered with densely spaced, very fine granules. Eye moderately small; about 26 dorsoventral files with maximally 8 lenses per file $( \pm 26 / 8)$. Weakly inflated anterior and posterior pygidial pleural bands. Interpleural furrows narrow (exsag.) but developed throughout.

Description. Cephalon weakly vaulted. Anterior border narrow in front of glabella with weakly developed anterior ledge. Length (sag.) of glabella anterior to S0 slightly greater than width (tr.) across frontal lobe. Axial furrows firmly incised, straight between S0 and S2, abaxially arched near L3 and frontal lobe. S0 firmly incised. Lateral glabellar furrows S1 anteriorly curved adaxially, deep; S2 and S3 more or less straight, moderately firmly impressed. Occipital ring about as wide (tr.) as glabella across L3. Lateral glabellar lobes L1 narrow (exsag.); L2 much larger (exsag.) than L1, of subtrapezoidal outline; L3 slightly larger (exsag.) than L2, of subtrapezoidal outline. Frontal glabellar lobe well demarcated anteriorly and laterally by distinct grooves. Median portion of glabella between occipital ring and anterior lobe not sunk. Librigenal field broadening (tr.) posteriorly, especially beyond $\delta$; bearing a mixture of shallow pits and fine, dense granulation; weakly vaulted (tr.). Lateral border dorsally flattened; lateral border furrow narrow. Fixigenal field bearing similar sculpture as librigenal field. Posterior border furrow broadest posterior of eye. Genal spines short.

Thorax is unknown.

Pygidium of rounded triangular in outline. Axis comprises up to 11 rings; anterior six rings successively narrowing (tr.) backwards, separated by firmly impressed inter-ring furrows; remaining rings barely tapering backwards, separated by increasingly shallow interring furrows. Six pairs of distinct, straight, successively shorter pleurae with rib segmentation of the prorotundifrons-type. Proximal end of sixth pleura meets seventh axial ring. Faintly curved, dagger-shaped pygidial pleural spines, about as long as associated pleural ribs. Terminal lappet with broad basis; short, with sharp, upward directed tip. Pygidium covered with densely spaced, fine granules.

Discussion. Treveropyge prorotundifrons from the lower Emsian of the Eifel differs from the new species in having a narrower (tr.) glabella anterior of S0 with coarser and less densely spaced granulation, larger eyes with maximally 12 lenses per dorsoventral file, a narrower (tr.) librigenal field lateral of the eye, shallow S2, more anteriorly directed S3 that is connected with axial furrow without shallowing, more inflated (exsag.) pygidial pleural bands, and longer, narrower pygidial pleural spines.

Basse et al. (2006) described a new species, Pilletina luxemburgensis, based on pygidia and a cephalon from the Our Formation in Luxemburg. These workers selected a large 

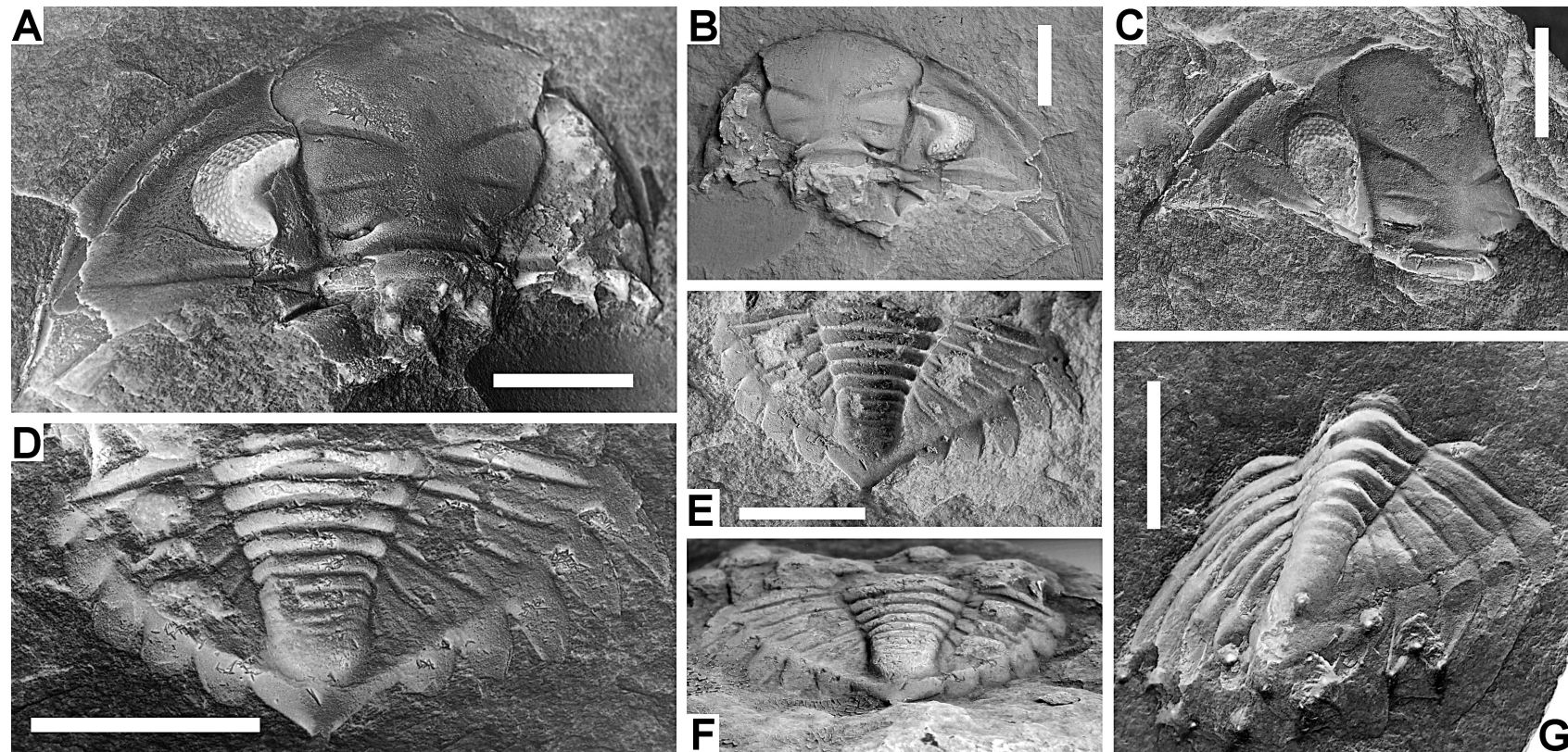

$\mathbf{F}$

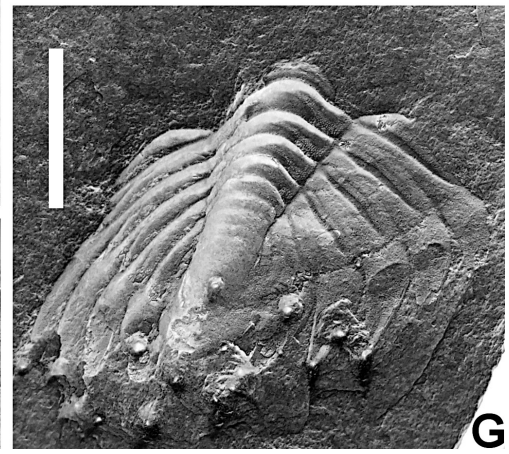

Figure 7. Treveropyge hellemondi sp. nov. from the lower part of the Our Formation at B-117, Breitfeld.

A, B. Paratype external mould (A) and associated plaster cast (B) of a cephalon, IRSNB a13455a+c, in dorsal view. C. Paratype external mould of a cephalon, IRSNB a13456b, in dorsal view. D-F. Holotype external mould (D) and plaster cast (E, F) of a pygidium, IRSNB a13457a+b, in dorsal (D, E) and oblique posterior (F) views. G. Paratype external mould of a pygidium, IRSNB a13458, in dorsal view (note the extensive tectonic deformation of this specimen).

All scale bars represent $5 \mathrm{~mm}$.

pygidium as the holotype while mentioning striking similarities between their paratype cephalon and that of T. prorotundifrons. Basse et al. (2006) argued that their cephalon could also be a Treveropyge but chose to include it in P. luxemburgensis instead. Likewise, the pygidia and cephala from Breitfeld have not been found associated yet they are assigned to a single new species. These specimens are generally similar to known Treveropyge species (pygidia and cephala alike), especially to its type species, and we see no reason to doubt that they are all congeneric. Our specimens represent the only asteropygines in the Breitfeld locality with the exception of a single pygidial fragment of indeterminate yet clearly different generic identity (see below). The cephalon of $P$. luxemburgensis is similar to those of T. hellemondi; given their stratigraphic proximity these specimens might be conspecific or at least closely related. The pygidium of P. luxemburgensis is easily discriminated from that of $T$. hellemondi in having distinct median nodes on the axial rings, deeper pleural and interpleural furrows, and longer and much more robust pleural spines and median lappet.

\section{Asteropyginae gen. \& sp. indet.}

(Fig. 3J)

Material. IRSNB a13450, external mould of a fragmentary pygidium, from the lower part of the Our Formation of B-117, Breitfeld.

Discussion. A single pygidial fragment is available which has posteriorly directed rings in the posterior part of the axis; each ring bears a median tubercle. This specimen is not a Treveropyge but may belong to Dunopyge Struve in Becker \& Jansen, 1998 or, less probably, to Pilletina Haas, 1970. All these genera are known from early Emsian strata in the Ardenno-Rhenish Mountains.

\section{Biostratigraphy}

The current and previously published data on trilobites from Belgium, Luxemburg and northern France enable the first rudimentary steps towards Emsian biostratigraphic correlations based on trilobites (Fig. 8).

Firstly, it is important to underline the Pragian age of the trilobites recorded from the "Quartzophyllades de Longlier" in the Longlier area (Fig. 2A), Neufchâteau Synclinorium, by van Viersen \& Prescher (2009). As pointed out by Dejonghe (2013,
2019), the Longlier and Amonines facies of the mid-Pragian Villé Formation pass laterally into one another, and the usage of the Longlier Formation as proposed by Vandenven (1990) is unnecessary.

\subsection{Emsian trilobites in Belgium, Luxemburg and northern France}

Breitfeld trilobite association; Breitfeld, Belgium; Our Formation, probably lower part: Arduennella maillieuxi, Burmeisterella quadrispinosa, Treveropyge hellemondi, Wenndorfia sp. and Asteropyginae gen. \& sp. indet.

Reideschbaach trilobite association; Reideschbaach, Luxemburg; Our Formation, probably basal part: Paralepidoproetus cf. acrodactylium (Haas, 1968), Luxembourgcoryphe lunkenheimeri Basse \& Franke, 2006, Cyphaspis sp., Wenndorfia plana (Koch, 1883) ssp., Burmeisterella cf. quadrispinosa, Spiniscabrella sp., Acastava faberi Basse \& Franke, 2006, Pilletina luxemburgensis Basse, Müller \& Franke, 2006, Pilletina oeslingiana Basse \& Franke, 2006, Rhenops australocustos Basse, Müller \& Franke, 2006, Braunops? sp. and Leonaspis? sp. See Basse \& Franke (2006) and Basse et al. (2006).

Burg Reuland trilobite fauna; Auf Schleid quarry near Burg Reuland, Belgium; Our Formation, probably upper part: Digonus ornatus ornatus (Koch, 1883), Rhenops cf. index (Richter \& Richter, 1943), Treveropyge cf. prorotundifrons and Acastava sp. See Franke (2006). A preliminary study of the macrofauna including the trilobites was published by Hellemond et al. (2019).

Burmeisterella delattrei (Pillet \& Waterlot, 1983), upper part of the Vireux-Molhain, France; Vireux Formation. See chapter Systematic palaeontology herein.

Mormont trilobite fauna; Mormont-Érezée area, Belgium; upper part of the Vireux Formation ("grès blancs de Mormont" of Maillieux \& Demanet, 1929, of restricted distribution in the area North of Amonines; see also Dejonghe, 2008): Digonus ornatus ornatus, Burmeisterella armata, Acastava sp. and Treveropyge sp. Specimens in the Maillieux collections were examined by one of us (AVV) and will be described in a future paper.

Vireux trilobite fauna; Vireux-Molhain, France; Chooz Formation ("schistes rouges de Winenne" of Maillieux, 1932): Digonus intermedius (Viëtor, 1919), Digonus mosanus (Maillieux, 1932) (synonymy of $D$. mosanus with $D$. intermedius was proposed by Wenndorf, 1990 but subsequently rejected by van Viersen, 2015), and Acastava cf. schmidti (Richter, 1909). 


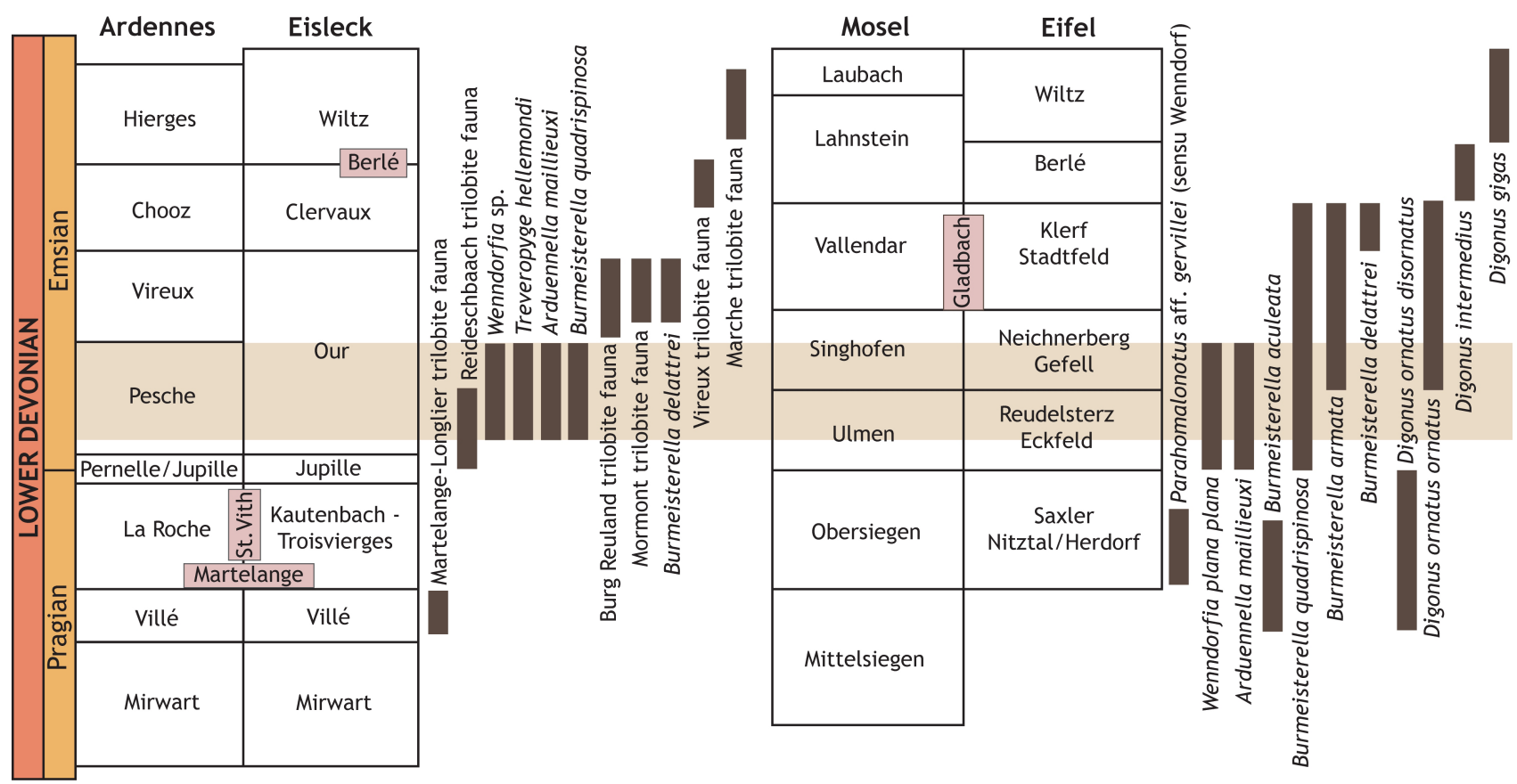

Figure 8. Pragian to Emsian stratigraphic units and selected trilobite occurrences in the Ardenno-Rhenish Mountains.

See Maillieux (1932) and van Viersen (2013).

Marchetrilobite association; disused quarry nearGrimbiémont, Belgium; Hierges Formation (or Hierges-Hampteau complex according to the revised geological map): Acastava lerougei van Viersen, 2013, Delocare sp. and Treveropyge sp. See van Viersen (2013).

Olloy trilobite occurrence; Olloy-sur-Viroin, Belgium; Hierges Formation: Leonaspis? sp. See van Viersen (2013).

\subsection{Comparisons to the Rhenish Mountains}

As pointed out previously by van Viersen \& Prescher (2009) the Breitfeld association includes two index fossils for the lower Emsian in the Rhenish Mountains. These are Arduennella maillieuxi (Ulmen and Singhofen groups) and Burmeisterella quadrispinosa (Ulmen to Vallendar groups).

The Burg Reuland trilobite fauna is known from ex-situ finds in the Auf Schleid quarry. The association of Digonus ornatus ornatus, Rhenops cf. index, Treveropyge cf. prorotundifrons and Acastava is known from the Gladbach Schichten in the Eifel (Vallendar Group). This is consistent with the viewpoint of Franke (2006) who suspected a Vallendar age for this quarry although he attributed it more specifically to the Klerf (Clervaux) Formation. De Baets et al. (2013) considered this outcrop to be middle or late early Emsian (Singhofen or Vallendar equivalent) based on brachiopods.

The Mormont trilobite fauna occurs locally in the area between Mormont and Érezée. The occurrences of Burmeisterella armata and abundant Digonus ornatus ornatus indicate a Singhofen-Vallendar age.

Burmeisterella delattrei occurs in the upper part of the Vireux Formation in Vireux-Molhain. This species is considered by us to be conspecific with $B$. vixarmata specimens recorded by Wenndorf (1990) from the Klerf Formation in Luxemburg and the Eifel. Either these levels should be correlated or B. delattrei ranges from the middle to the upper part of the Vallendar Group.

The poorly diversified Vireux trilobite fauna of the Chooz Formation is locally known from old quarries in the VireuxMolhain area. Digonus intermedius is a useful stratigraphic marker since it is known in the Rhenish Mountains exclusively from the lower part of the Lahnstein Group. However, Müller (in Basse \& Müller, 2004) recorded Digonus $\mathrm{cf}$. intermedius from the Wiltz Formation in the Eifel while noting differences with typical material of $D$. intermedius. Thus, this species is potentially eligible for subdivision.

The Marche trilobite association shares all taxa at the genus level with the much more diversified trilobite fauna of the lateral Wiltz Formation in the Eifel and Luxemburg (Franke, 2010).

The Olloy trilobite occurrence is based on a single odontopleurine specimen that almost certainly belongs to Leonaspis. Putative congeners furthermore occur in the lateral Wiltz Formation in the Eifel and Luxemburg (Franke, 2010).

\section{Palaeobiogeographic affinities of the Breitfeld trilobite association}

The Breitfeld association does not contain any trilobite genus that is exclusive of the Ardenno-Rhenish Mountains. Treveropyge also occurs in Spain and possibly in France and Morocco (Basse, 2003). Members of Wenndorfia are widely distributed in (peri-) Gondwana, i.e., in Morocco (Schraut, 2000), the Czech Republic (Chlupáč \& Kolář, 2001; van Viersen \& Prescher, 2009), New Zealand, Turkey, Poland, France (Sandford, 2005), Romania (Iordan, 1981) and Portugal (Caprichoso, 2019). Burmeisterella, which is a characteristic component of homalonotid faunas along the southern margin of Laurussia, was recently reported in Brazil (de Carvalho, 2005) and in Portugal (AVV, pers. comm. with C. Caprichoso in February 2018; Caprichoso, 2019). These records extend its palaeogeographic distribution to Gondwana. Despite many claims by fossil dealers on the Internet, Burmeisterella is not known to occur in Morocco; all those specimens appear to be amalgamated Scabrella or Spiniscabrella parts or complete falsifications. The absence of Burmeisterella in Morocco is arguably due to unsuitable facies there. There is a stratigraphic gap between the earliest occurrences of members of Arduennella in the Pragian of Morocco (Schraut, 2000) and the ArdennoRhenish Mountains (lower Emsian). Based on these data it has to be assumed that Arduennella is of Gondwanan origin and that a member migrated to the southern margin of Laurussia in the late Pragian or early Emsian. In this respect the recognition of Arduennella in the Emsian of Romania (peri-Gondwana) by Basse \& Müller (2016) (see Iordan, 1981, pl. 19, fig. 7) is worth mentioning.

De Baets et al. (2013) concluded that the first appearances of early ammonoids in the Our Formation in Burg Reuland and more or less coeval localities in the Rhenish Mountains might be related to a regional transgressive event basally in the Singhofen Group rather than a global transgression (Becker \& Kullmann, 
1996). This appears to not be the case, at least, for the trilobites. The Emsian was a period of noteworthy trilobite migrations enabled by repeated sea level rises. Chlupáč (1994) and Chlupáč \& Kolář (2001) noted in particular the reduced provinciality of early Emsian trilobites and the increasingly mixed "Rhenish" and "Hercynian" associations along the southern margin of Laurussia and northern margin of Gondwana. This viewpoint is consistent with the results of studies on early Emsian trilobites in the Ardenno-Rhenish Mountains (Basse \& Franke, 2006; van Viersen, 2015; van Viersen \& Prescher, 2009; the present note), the Armorican Massif, the Cantabrian Mountains and North Africa (e.g. Chlupáč et al., 2000). Basse et al. (2006) noticed similarities between their Reideschbaach association in the Our Formation and the trilobite fauna of the Cantabrian Mountains. They believed that attributing these to an early Emsian migration event would be premature because the possibility that an earlier migration event followed by convergence in the early Emsian could not be excluded. Van Viersen \& Prescher (2009) and van Viersen (2013) argued that interactions between the trilobite faunas of southern Laurussia and northern Gondwana occurred intermittently throughout the Early Devonian, with facies development and the availability of suitable migration routes as the main controlling factors. According to van Viersen \& Prescher (2009) and van Viersen (2015) the earliest records of "Hercynian" trilobites come from mid-Pragian deposits in southern Belgium; their presence there continued until in the Middle Devonian with brief interruptions in the fossil record. Such intermissions can, at least in part, be correlated with temporary expansions of unfavourable littoral facies (e.g. the regressive deposits of the mid-Emsian Chooz Formation in South Belgium and northern France). Scarcity of data is also an important factor here; this is due to a general sampling bias for Early Devonian strata in the Ardenno-Rhenish which remain poorly prospected for trilobites.

\section{Conclusions}

The co-occurrence of $A$. maillieuxi and B. quadrispinosa in the Breitfeld outcrop indicates an early lower Emsian age. Contemporary stratigraphic divisions lead us to suggest that this locality is situated within the lower part of the Our Formation (lower Emsian) rather than in the Sankt Vith facies (Pragian), but we wish to emphasise that this assignment is based exclusively on circumstantial evidence. A first correlation attempt for Emsian trilobites in the Ardennes and Rhenish Mountains reveals that the greatest potential for trilobite-based zonations appears to lie with the homalonotids, many species of which are shared between both regions. Yet classifications of homalonotid species are not always unambiguous when considering problems with the definitions of some members of Burmeisterella and the need for a reappraisal of the monotypic Arduennella. Species of the other trilobite families demonstrate a more endemic character, limiting their potential to biostratigraphic correlations. In some cases (e.g. Burg Reuland) the association of certain trilobites could help to increase resolution of the comparisons. It should be borne in mind, however, that many taxa are facies dependent, lending associations a temporal or local character and not necessarily implying a correlative age.

\section{Acknowledgements}

A. Folie and A. Drèze provided access to the studied material in the Maillieux collection housed by the IRSNB. R. Speijer and R. Van Bael let us go over the Asselberghs collection in the Atrecht College and Geo-instituut of the Katholieke Universiteit Leuven. M. Basse (Senckenberg Institute) shared information about type specimens stored in the collections of the Senckenberg Institute. L. Dejonghe (IRSNB) participated in helpful discussions on the regional geology of the studied area. S. Goolaerts (IRSNB) helped us to locate the Breitfeld locality. B. Magrean (Roetgen) joined the authors on a field excursion in 2018 to explore the surroundings of Breitfeld. The manuscript benefited from the astute review comments provided by M. Alberti (Landesamt für Geologie und Bergbau Rheinland-Pfalz), M. Basse (Senckenberg Institute) and B. Delcambre (Université catholique de Louvain). We are grateful to these persons for their support.

\section{References}

Alberti, M., 2008. Eine interessante Homalonoten-Gesellschaft aus dem Unterems (Unterdevon) des westlichen Hintertaunus. Mainzer geowissenschaftliche Mitteilungen, 36, 37-44.

Asselberghs, E., 1921. Le Dévonien inférieur du Cercle de Malmédy. Bulletin de la Société belge de Géologie, de Paléontologie et d'Hydrologie, 31, 134-155.

Asselberghs, E., 1923. Homalonotus maillieuxi, espèce nouvelle du Hunsruckien de la Belgique. Bulletin de la Société belge de Géologie, de Paléontologie et d'Hydrologie, 33, 29-32.

Asselberghs, E., 1927. Siegenien, Siegenerschichten, Hunsruckschiefer et Taunusquarzit. Bulletin de la Société belge de Géologie, de Paléontologie et d'Hydrologie, 36, 206-222.

Asselberghs, E., 1946. L'Éodévonien de l'Ardenne et des régions voisines. Mémoires de l'Institut Géologique de l'Université de Louvain, 14, $1-598$.

Basse, M., 2003. Eifel-Trilobiten. 2. Phacopida 1. Goldschneck Verlag, Korb, 198 p.

Basse, M., 2007. Homonymie, objective und subjective Synonymie sowie weitere nomenklatorische Probleme bei deutschen und anderen Trilobitentaxa. Senckenbergiana lethaea, 87, 223-225. https://doi. org/10.1007/BF03043916

Basse, M. \& Franke, C., 2006. Marine Faunen aus dem frühen Unteremsium (Unterdevon) des Givonne-Oesling-Antiklinoriums (Luxemburg). Ferrantia, 46, 7-41.

Basse, M. \& Müller, P., 2004. Eifel-Trilobiten III. Corynexochida, Proetida (2), Harpetida, Phacopida (2), Lichida. Quelle \& MeyerVerlag, Wiebelsheim, $260 \mathrm{p}$.

Basse, M. \& Müller, P., 2016. Trilobiten aus dem Ober-Emsium und frühen Eifelium der südlichen Lahnmulde (Rupbach-Schiefer, LeunSchiefer und Ballersbach-Kalk). Abhandlungen der Senckenberg Gesellschaft für Naturforschung, 572, 1-329.

Basse, M., Müller, P. \& Franke, C., 2006. Neue Daten zu den Trilobiten aus dem frühen Unteremsium (Ulmen-Unterstufe; Unterdevon) vom Reideschbaach (Luxemburg; Givonne-Oesling-Antiklinorium; Rhenohercynikum). Senckenbergiana lethaea, 86, 243-259. https:// doi.org/10.1007/BF03043491

Basse, M. \& Weddige, K., 2004. Typen und Typoide des SenckenbergMuseums, Nr. 86. Typen-Katalog der Trilobiten-Sammlung des Naturmuseums und Forschungsinstitut Senckenberg. Senckenbergiana lethaea, 84, 141-172. https://doi.org/10.1007/ BF03043469

Becker, R.T. \& Kullmann, J., 1996. Paleozoic ammonoids in space and time. In Landman, N.H., Tanabe, K. \& Davis, R.A. (eds), Ammonoid Paleobiology. Plenum Press, New York, Topics in Geobiology, 13, 711-753. https://doi.org/10.1007/978-1-4757-9153-2_17

Cambier, G. \& Dejonghe, L., 2010. Systematic inventory and ordering of faults in Belgium - Part 1. Geological Survey of Belgium Professional Paper, 307, 1-95.

Caprichoso, C., 2019. Trilobites Calymenina do Devónico de Portugal - uma Revisão. Unpublished Master Thesis, Universidade Nova de Lisboa, Lisboa, 96 p.

Chlupáč, I., 1994. Devonian trilobites - Evolution and events. Geobios, 27, 487-505. https://doi.org/10.1016/S0016-6995(09)90029-8

Chlupáč, I. \& Kolář, P., 2001. First homalonotid trilobites from the Devonian of Bohemia and their significance. Bulletin of the Czech Geological Survey, 76, 179-186.

Chlupáč, I., Feist, R. \& Morzadec, P., 2000. Trilobites and standard Devonian stage boundaries. Courier Forschungsinstitut Senckenberg, 220, 87-98.

De Baets, K., Goolaerts, S., Jansen, U., Rietbergen, T. \& Klug, C., 2013. The first record of Early Devonian ammonoids from Belgium and their stratigraphic significance. Geologica Belgica, 16, 148-156.

De Carvalho, M.G.P., 2005. First occurrence of Burmeisterella (Trilobita, Homalonotidae) from the Devonian of Brazil (Parecis Basin), with description of a new species. Arquivos do Museu Nacional, Rio de Janeiro, 63, 451-458.

Dejonghe, L., 2008. Carte géologique de Wallonie : Hotton - Dochamps 55/5-6. 1/25 000. Namur, Ministère de la Région wallonne, Direction générale des ressources naturelles et de l'environnement, avec une notice explicative de $88 \mathrm{p}$.

Dejonghe, L., 2013. Geology of the Ardenne Anticlinorium, in the Amberloup - La Roche-en-Ardenne - Houffalize sector. The faults of the La Roche Syncline and the overturned Taverneux Anticline. Geologica Belgica, 16, 196-205.

Dejonghe, L., 2019. Carte géologique du Luxembourg au 1:25 000. Feuille $n^{\circ} 1$ - Troisvierges : Notice explicative. Bulletin du Service géologique du Luxembourg, 18, 5-35. 
Dejonghe, L., Colbach, R. \& Goemaere, E., 2017. The lithostratigraphy of the lower Devonian formations of the Eisleck region (northern Luxembourg). Comparison with their Belgian lateral equivalents. Geologica Belgica, 20, 33-42. http://dx.doi.org/10.20341/ gb. 2017.001

Franke, C., 2006. Die Klerf-Schichten (Unter-Devon) im Großherzogtum Luxemburg, in der Westeifel (Deutschland) und im Gebiet von Burg Reuland (Belgien): fazielle und biostratigraphische Deutungen. Ferrantia, 46, 42-96.

Franke, C., 2010. Marine Fauna der Wiltz-Schichten (Ober-Emsium, Unter-Devon) der Mulde von Wiltz und der Daleider Mulden-Gruppe (Luxemburg, Deutschland): Teil 1. In Franke, C. (ed.), Beiträge zur Paläontologie des Unterdevons Luxemburgs. Ferrantia, 58, 5-62.

Hellemond, A., Van Viersen, A.P., Magrean, B., Lerouge, F., Taghon, P. \& Kesselaer, I., 2019. De groeve van Steffeshausen nabij BurgReuland. Spirifer, 43/2, 2-23.

Iordan, M., 1981. Study of Silurian and Devonian faunas from the eastern part of the Moesian Platform. Institut de Géologie et de Géophysique, Mémoires, 30, 115-222.

Jansen, U., Plodowski, G., Schindler, E. \& Weddige, K., 2004. The Pragian at Assa (SW Dra Valley, Morocco). Documents de l'Institut Scientifique, Rabat, 19, 64-68.

Kennedy, R.J., 1994. British Devonian trilobites. Part 1. Monograph of the Palaeontographical Society, 148 (595), 1-33.

Maillieux, E., 1932. La faune de l'Assise de Winenne (Emsien moyen) sur les bordures méridionale et orientale du bassin de Dinant. Mémoires du Musée royal d'Histoire naturelle de Belgique, 52, 1-102.

Maillieux, E., 1933. Terrains, roches et fossiles de la Belgique. Musée royal d'Histoire naturelle de Belgique. Bruxelles, $217 \mathrm{p}$.

Maillieux, E., 1940. Le Siegenien de l'Ardenne et ses faunes. Bulletin de 1'Institut royal des Sciences naturelles de Belgique, 16, 1-23.

Maillieux, E. \& Demanet, F., 1929. L'échelle stratigraphique des terrains primaires de la Belgique. Bulletin de la Société belge de Géologie, de Paléontologie et d'Hydrologie, 38, 124-131.

Müller, P., 1997. Fossillagerstätten im Westerwald. Westerburger Hefte, $25,1-52$.

Müller, P., 2011. Fossilien aus dem Westerwälder Devon und Karbon. Aufschluss, 62, 219-232.

Müller, P. \& Alberti, M., 2010. Burmeisterella vixarmata aus der KlerfFormation in Nord-Luxemburg (Trilobita, oberes Unter-Devon). In Franke, C. (ed.), Beiträge zur Paläontologie des Unterdevons Luxemburgs. Ferrantia, 58, 63-71.

Pillet, J. \& Waterlot, M., 1983. Découverte d'une nouvelle espèce de Trilobite (Homalonotidae) dans les grès de Vireux (Ardennes, France). Annales de la Société Géologique du Nord, 52, 183-185.

Sandford, A., 2005. Homalonotid trilobites from the Silurian and Lower Devonian of south-eastern Australia and New Zealand (Arthropoda: Trilobita: Homalonotidae). Memoirs of Museum Victoria, 62, 1-66. http://doi.org/10.24199/j.mmv.2005.62.1

Schraut, G., 1998. Trilobiten aus dem Unter-Devon des südlichen Antiatlas (Marokko) - ihre Bedeutung für die zeitliche Korrelation zwischen Rheinischer und Herzynischer Fazies. Senckenbergiana lethaea, 77, 61-69. https://doi.org/10.1007/BF03043733

Schraut, G., 2000. Trilobiten aus dem Unter-Devon des südöstlichen Anti-Atlas, Süd-Marokko. Senckenbergiana lethaea, 79, 361-433. https://doi.org/10.1007/BF03043647

Størmer, L., 1980. Sculpture and microstructure of the exoskeleton in chasmopinid and phacopid trilobites. Palaeontology, 23, 237-271.

Tomczykowa, E., 1975. The trilobite subfamily Homalonotinae from the Upper Silurian and Lower Devonian of Poland. Acta Palaeontologica Polonica, 20, 3-46.

Vandenven, G., 1990. Explications de la carte géologique du Synclinorium de l'Eifel. (Région de Gouvy - Sankt-Vith - Elsenborn). Annales de la Société Géologique de Belgique, 113, 103-113.

Van Viersen, A.P., 2013. Latest Early to early Middle Devonian acastid trilobites from the eastern part of the Dinant Synclinorium, Belgium (Rhenohercynian Zone). In Holloway, D.J. \& Laurie, J. (eds), SiluroDevonian Studies. 2. Memoirs of the Association of Australasian Palaeontologists, 44, 1-10.

Van Viersen, A.P., 2015. Trilobites du Dévonien des Ardennes (zone rhéno-hercynienne): biostratigraphie, évolution et événements. Fossiles, Revue française de Paléontologie, 11, 5-24.

Van Viersen, A.P. \& Prescher, H., 2009. Trilobites from the Longlier Formation (Lower Devonian; Neufchâteau Synclinorium, southeast Belgium): first record of Pragian associated "Rhenish" and "Bohemian" assemblages from the Ardennes. Bulletin de 1'Institut royal des Sciences naturelles de Belgique, Sciences de la Terre, 29, 5-26.

Wenndorf, K.-W., 1990. Homalonotinae (Trilobita) aus dem Rheinischen Unter-Devon. Palaeontographica (A), 211, 1-184.
Whittington, H.B. \& Kelly, S.R.A., 1997. Morphological terms applied to Trilobita. In Kaesler, R.L. (ed.), Treatise on Invertebrate Paleontology, Part O, Arthropoda 1. Trilobita, revised. Volume 1: Introduction, Order Agnostida, Order Redlichiida. Geological Society of America, Boulder, Colorado and University of Kansas Press, Lawrence, Kansas, 313-329.
Manuscript received 23.10.2019, accepted in revised form 09.12.2019, available online 27.01.2020. 